\title{
PENINGKATAN KEMAMPUAN BERPIKIR KRITIS MATEMATIS SISWA MELALUI REPCIPROCAL TEACHING DI KELAS VIII SMP NEGERI 1 BUKIT
}

\author{
Rosliana Harahap ${ }^{1}$, Betri Yustianingrum ${ }^{2}$ Ilhamdi $^{3}$ \\ STAIN Gajah PutihTakengon, Aceh Tengah, Aceh \\ E-mail: r05liana007@gmail.com
}

\begin{abstract}
Abstrak: Kemampuan berpikir kritis matematis adalah kemampuan untuk menganalisis, menafsirkan, menalar, memprediksi, mengevaluasi dan merefleksikan serta dapat mendorong berkembangnya pemahaman dan penghayatan siswa terhadap prinsip, membantu meningkatkan potensi dan rasa percaya diri siswa dalam matematika. Penulis melihat kemampuan berpikir kritis matematis siswa di SMP Negeri 1 Bukit Bener Meriah masih kurang, khususnya pada pelajaran matematika materi Relasi dan fungsi. Oleh sebab itu, peneliti memilih pendekatan pembelajaran Reciprocal teaching sebagai salah satu alternative dalam meningkatkan kemampuan berpikir kritis matematis siswa. Adapun tujuan pada penelitian ini untuk mengetahui pengaruh penggunaan strategi Reciprocal teaching terhadap kemampuan berpikir kritis matematis siswa di SMP Negeri 1 Bukit Bener Meriah. Penelitian ini menggunakan penelitian eksperimen dengan pendekatan kuantitatif dengan jumlah siswa seluruh kelas VIII sebanyak 120 siswa. Dalam pengambilan sampel penulis menggunakan teknik purposive sampling. Berdasarkan pengambilan sampel peneliti memilih kelas VIII.1 sebagai kelas eksperimen. Berdasarkan hasil perhitungan gain diperoleh peningkatan kemampuan berpikir kritis matematis siswa kelas VIII SMP N 1 Bukit dalam katagori sedang.
\end{abstract}

Kata Kunci: Strategi pembelajaran Reciprocal teaching, kemampuan Berpikir kritis matematis, peningkatan

\section{Pendahuluan}

Banyak dari kalangan masyarakat yang berpendapat bahwa matematika merupakan pelajaran yang banyak menuntut kemampuan yang relatif tinggi. Sehingga sebahagian anak didik mengalami kesulitan dan jenuh serta menyerah ditengah-tengah perjalanan dan tidak berminat untuk menekuninnya. Hal ini menyebabkan hasil belajar matematika relatif rendah dibandingkan dengan pelajaran yang lain. Pengajaran kemampuan berpikir kritis memiliki beberapa kendala dan menjadi permasalah dalam belajar matematika yaitu: (1) Terlalu dominannya peran guru di sekolah sebagai penyebar ilmu atau sumber ilmu, sehingga siswa hanya dianggap sebagai sebuah wadah yang akan diisi dengan ilmu oleh guru. (2) Kendala lain yang sebenarnya sudah cukup klasik namun memang sulit dipecahkan, adalah sistem penilaian prestasi siswa yang lebih banyak didasarkan melalui tes-tes yang sifatnya menguji kemampuan kognitif tingkat rendah. (3) Siswa belum belum sepenuhnya menguasai apa yang diajarkan oleh gurunya. (4) Siswa yang dicap sebagai siswa yang pintar atau sukses adalah siswa yang lulus ujian. Ini merupakan masalah lama yang sampai sekarang masih merupakan polemik yang cukup seru bagi dunia pendidikan di Indonesia.

Setiap orang dapat belajar berpikir dengan kritis karena otak manusia secara konstan berusaha memahami pengalaman. Belajar yang banyak memerlukan berpikir secara kritis yaitu belajar matematika, dimana matematika kaya akan simbol-simbol dan angka-angka yang semuanya memerlukan pemikiran untuk dapat mengartikan dan menentukan penyelesaian yang ada didalamnya matematika yang timbul karena pikiran-pikiran manusia, yang berhubungan dengan 
idea, proses, dan penalaran. Berpikir kritis membantu untuk memahami bagaimana sebaiknya memandang diri sendiri, bagaimana memandang dunia, dan bagaimana seharusnya berhubungan dengan orang lain. Berpikir kritis merupakan sebuah keterampilan hidup, bukan hanya dikembangkan dibidang akademik melainkan dapat dikembangkan oleh setiap orang, maka dari itu berpikir kritis harus diajarkan di sekolah dasar, SMP, dan SMA agar dapat menghadapi era persaingan global, karena tingkat kompleksitas permasalahan dalam segala aspek kehidupan modern yang semakin tinggi.

Berdasarkan wawancara pada tanggal 20 April 2017 dengan ibu Sakem, SPd, salah seorang guru matematika di SMP Negeri 1 Bukit, "dia mengatakan berdasarkan hasil pengamatan peneliti yang dilakukan di kelas VIII semester 1 kemampuan menjawab soal berpikir kritis siswa belum maksimal pada materi Fungsi, yang biasanya diharapkan dapat mencapai 100\%, kini semua siswa hanya mampu mencapai 50\% saja. Dari gambaran diatas diperoleh kemampuan berpikir kritis matematis siswa masih rendah, untuk itu perlu adanya metode pembelajaran yang dapat meningkatkan kemampuan berpikir kritis matematis siswa.

\section{Tinjauan Pustaka}

\section{Kemampuan Berpikir Kritis Matematis Siswa}

Berpikir kritis menurut Kamus Besar Bahasa Indonesia adalah menggunakan akal budi untuk mempertimbangkan dan memutuskan sesuatu secara tajam dalam penganalisaannya. Berpikir kritis matematis adalah kemampuan intelektual yang dimiliki seseorang untuk memahami permasalahan matematika. Mereka mampu menganalisis permasalahan tersebut, dan dapat memutuskan solusi yang sesuai dari permasalahan tersebut. Berpikir kritis matematis juga dapat didefinisikan sebagai kemampuan berpikir logis dan reflektif yang fokus pada cara mengambil keputusan yang dapat dipercaya. Oleh karena itu, seseorang yang memiliki kemampuan berpikir kritis matematis memiliki kemampuan intelektual dengan berpikir logis dan reflektif dalam memahami permasalahan matematika, menganalisis permasalahan, dan memutuskan solusi yang tepat (Rully \& Charitas, 2017).

Berpikir Kritis berarti meletakkan hubungan antar bagian pengetahuan yang diperoleh manusia. Berpikir sebagai proses menentukan hubungan-hubungan secara bermakna antara aspek-aspek dari suatu bagian pengetahuan. Sedangkan bentuk aktivitas berpikir merupakan tingkah laku simbolik, karena seluruh aktivitas ini berhubungan dengan atau mengenai penggantian hal-hal yang konkrit. Menurut Oktavia Filda Yanti Rully \& Charitas (2017: vol 2, 2) Berpikir kritis matematis adalah kemampuan intelektual yang dimiliki seseorang untuk memahami permasalahan matematika. Mereka mampu menganalisis permasalahan tersebut, dan dapat memutuskan solusi yang sesuai dari permasalahan tersebut. Berpikir kritis matematis juga dapat didefinisikan sebagai kemampuan berpikir logis dan reflektif yang fokus pada cara mengambil keputusan yang dapat dipercaya. Oleh karena itu, seseorang yang memiliki kemampuan berpikir kritis matematis memiliki kemampuan intelektual dengan berpikir logis dan reflektif dalam memahami permasalahan matematika, menganalisis permasalahan, dan memutuskan solusi yang tepat.

Menurut Ennis dalam Costa (1985: 16) memberikan definisi berpikir kritis adalah berpikir reflektif yang berfokus pada pola pengambilan keputusan tentang apa yang harus diyakini dan dilakukan. Berdasarkan definisi tersebut indikator berpikir kritis dapat dibagi menjadi 5 kelompok, yaitu: (1) memberikan penjelasan sederhana (elementary clarification), (2) membangun keterampilan dasar (basic support), (3) membuat 
kesimpulan (inferring), (4) membuat penjelasan lebih lanjut (advanced clarification), (5) mengatur strategi dan teknik (strategies and tactics). Kelima indikator tersebut diuraikan lebih lanjut atas sebelas komponen yaitu: (1) merumuskan masalah; (2) menganalisis argument; (3) menanyakan dan menjawab pertanyaan; (4) melakukan kredibilitas sumber informasi; (5) melakukan observasi dan menilai laporan hasil observasi; (6) membuat deduksi dan menilai deduksi; (7) membuat induksi dan menilai induksi; (8) mengevaluasi; (9) mendefinisikan dan menilai definisi; (10) mengedentifikasi asumsi; (11) memutuskan dan melaksanakan; (berinteraksi dengan orang lain). Dari penjelasan tersebut kemampuan berpikir kritis sangat penting, sehingga kemampuan berpikir kritis matematika harus diperbaiki, untuk memperbaikinya diperlukan suatu metode pembelajaran yang sesuai.

\section{Reciprocal Teaching (Pembelajaran Terbalik)}

Pengajaran terbalik terutama dikembangkan untuk membantu guru menggunakan dialog-dialog belajar yang bersifat kerja sama untuk mengajarkan pemahaman bacaanbacaan secara mandiri di kelas. Melalui pengajaran terbalik siswa diajarkan empat strategi pemahaman pengaturan diri spesifik yaitu: Merangkum, Menanyakan, Mengklarifikasi, Memprediksi. Reciprocal teaching (pengajaran terbalik) adalah suatu pendekatan terhadap pengajaran siswa akan strategi-strategi belajar. Pengajaran ini berdasar pada prinsi-prinsip pembuatan/pengajuan pertanyaan. Pengajaran terbalik mengacu pada sekumpulan kondisi belajar dimana siswa pertama-pertama mengalami sekumpulan kegiatan kognitif tertentu dan perlahan-lahn akan melakukan fungsi-fungsi itu sendiri. Menurut Reski Awaliah \& Ridwan Idris, (2015: 13) Reciprocal Teaching (pengajaran terbalik) adalah prosedur pengajaran yang digunakan Brown dan Palincsar untuk mengembangkan kemampuan kognitif. "Selain pemantauan kognitif, ada dua kegiatan kognitif lainnya yang amat penting dalam kaitan dengan keterampilan kognitif sehari-hari, yaitu pengambilan keputusan dan berpikir kreatif'. Sehingga dapat dijadikan sebagai salah satu alternatif metode pembelajaran yang cukup dianggap menarik, dan diharapkan dapat mendorong dan meningkatkan siswa untuk berpikir kreatif dan kritis dalam pembelajaran matematika.

Model pembelajaran reciprocal teaching terdiri dari empat strategi yang dimulai dari guru menugaskan siswa merangkum bacaan dan diakhiri dengan memprediksi materi yang akan di bahas selanjutnya. Secara singkat keempat strategi pendekatan reciprocal teaching adalah:

Tabel 1. Tahapan Aktivitas Reciprocal Teaching

\begin{tabular}{ll}
\hline \multicolumn{1}{c}{ Tahap } & \multicolumn{1}{c}{ Kegiatan Guru } \\
\hline Merangkum & $\begin{array}{l}\text { Guru menjelaskan tujuan pembelajaran kemudian guru } \\
\text { memberikan bahan ajar dan menugaskan siswa untuk } \\
\text { merangkum ari bahan ajar tersebut secara berkelompok. }\end{array}$
\end{tabular}

Membuat Pertanyaan

Menjelaskan
Guru membagikan LKS dan siswa yang menyelesaikan LKS secara berkelompok, guru turut memandu jika diperlukan siswa membuat pertanyaan dari bahan ajar atau LKS yang diberikan guru dan meyelesaikan bersama-sama dalam kelompoknya.

Guru menugaskan siswa untuk menjelaskan kepada teman satu kelaompoknya tentang materi yang telah didiskusikan. 
Perdiksi

Guru meminta siswa memprediksi soal materi tersebut yang lebih sulit dari soal yang telah diberikan sebelumnya dan memprediksi pertanyaan apa yang akan muncul dari diskusi atau penjelasan kelompoknya.

\section{Peningkatan}

Peningkatan yang dimaksud adalah peningkatan kemampuan komunikasi dan koneksi matematik siswa, yang ditinjau berdasarkan gain ternormalisasi dari perolehan skor pretes dan postes siswa (David,2002).

$$
\text { Gain ternormalisasi }(\mathrm{g})=\frac{\text { skor postes }- \text { skor pretes }}{\text { skorideal }- \text { skor pretes }}
$$

Kategori gain normal (g) menurut Meltzer (2002) adalah :

$$
\begin{aligned}
& \mathrm{g}<0,3 \quad ; \text { rendah } \\
& 0,3 \leq \mathrm{g}<0,7 ; \text { sedang } \\
& 0,7 \leq \mathrm{g} \quad ; \text { tinggi }
\end{aligned}
$$

Melalui penelitian ini akan diketahui pengaruh Reciprocal teaching terhadap kemampuan berpikir kritis matematis siswa. Reciprocal teaching akan memberikan pengaruh positif terhadap kemampuan berpikir kritis matematis siswa.

\section{Metode Penelitian}

\section{Pendekatan Penelitian}

Penelitian ini menggunakan pendekatan kuantitatif dengan metode Penelitian yang digunakan adalah metode penelitian kuasi eksperimen, yaitu "penelitian yang mendekati percobaan sungguhan dimana tidak mungkin mengadakan kontrol/memanipulasikan semua variabel yang relevan (Suharsimi, 2012).

\section{Waktu dan Tempat Penelitian}

Penelitian dilaksanakan di SMP Negeri 1 Bukit. Jln Baletu Simpang Tiga Kampung Babussalam kec. Bukit Kab. Bener Meriah. Penelitian ini dilaksanakan pada kelas VIII semester I tahun ajaran 2018/2019. Dalam hal ini yang menjadi populasi adalah semua murid kelas VIII SMP Negeri 1 Bukit. Teknik pengambilan sampel menggunakan teknik purposive sampling, yaitu pengambilan sampel dengan beberapa pertimbangan tertentu. Adapun yang menjadi sampel dalam penelitian ini kelas VIII.

\section{Desain Penelitian}

Penelitian ini menggunakan rancangan penelitian One Group Pretest Posttest Grup Design. Pada kelas eksperimen diberikan perlakuan berupa pembelajaran dengan strategi Recprocal Teaching. Paradigma penelitiannya dapat digambarkan (Sugiyono, 2015) sebagai berikut:

$$
\begin{array}{llll}
\mathrm{R} & \mathrm{O}_{1} & \mathrm{X} & \mathrm{O}_{2}
\end{array}
$$

Keterangan:

$\mathrm{R}=$ kelompok eksperimen 


$$
\begin{aligned}
& \mathrm{X}=\text { perlakuandenganstrategi Reciprocal Teaching } \\
& \mathrm{O}_{1}=\text { nilai pretest (sebelum diberidiklat/perlakuan) } \\
& \mathrm{O}_{2}=\text { nilai posttest (setelah diberidiklat/perlakuan) }
\end{aligned}
$$

Instrumen pengumpulan data yang peneliti gunakan dalam penelitian ini adalah lembar tes. Soal tes diberikan dalam bentuk uraian sebanyak 10 butir soal pengumpulan data yaitu menggunakan tehnik tes. Tes yang diberikan yaitu tes awal dan tes akhir

1. Teknik Pengumpulan Data

Teknik pengumpulan data merupakan cara-cara yang dapat digunakan oleh peneliti untuk pengumpulan data. Teknik pengumpulan data dalam suatu penelitian merupakan faktor yang penting demi keberhasilan penelitian tersebut. Sesuai dengan pendekatan yang digunakan, yaitu pendekatan kuantitatif dengan tujuan memperoleh data kemampuan belajar siswa antara yang diajarkan dengan menggunakan pembelajaran model inkuiri, maka untuk memperoleh data nilai tersebut peneliti akan melakukan:

a. Tes

Tes adalah suatu teknik pengukuran yang didalamnya terdapat berbagai pertanyaan, pernyataan, atau serangkaian tugas yang harus dikerjakan atau dijawab oleh responden.Tes dapat dibedakan atas beberapa jenis, dan pembagian jenis-jenis ini dapat ditinjau dari berbagai sudut pandang (Arifin, 2016).

\section{Teknik Analisis Data}

Setelah data terkumpul menganalisa data secara akurat dan objektif dalam penelitian, maka teknik yang digunakan dalam menganalisa adalah:

a. Uji normalitas

Uji normalitas bertujuan untuk mengetahui apakah dari data masing-masing kelompok dalam penelitian ini berdistribusi normal atau tidak.

b. Uji Homogenitas

Untuk mengetahui suatu data homogen atau tidak ,digunakan uji homogenitas (uji kesamaan dua varians) menggunakan uji varian terbesar dibandingkan dengan varian terkecil.

c. Uji Gain

Hasil tes awal dan tes akhir siswa dianalisis terlebih dahulu untuk mengetahui tingkat kemampuan berpikir kritis matematis siswa sebelum dan sesudah penggunaan model pembelajaran Repciprocal Teaching. Besarnya peningkatan sebelum dan sesudah pembelajaran dihitung dengan rumus gain yang ternormalisasi (normalized Gain) yang di kembangkan Oleh Hake sebagai berikut:

$$
\text { Gain ternormalisasi }(\mathrm{g})=\frac{\text { skorpostes }- \text { skorpretes }}{\text { skorideal }- \text { skorpretes }}
$$

Kategori gain ternormalisasi (g) menurut Hake yang kemudian penulis modifakasi (Sundayana, 2014) sebagai berikut: 
Tabel 2. Interprestasi Gain Ternormalisasi yang Dimodifikasi

\begin{tabular}{rr}
\hline Nilai Gain Ternormalisasi & Interpretasi \\
\hline$-1,00 \leq \mathrm{g}<0,00$ & Terjadi penurunan \\
$\mathrm{g}=0,00$ & Tetap \\
$0,00<\mathrm{g}<0,30$ & Rendah \\
$0,30 \leq \mathrm{g}<0,70$ & Sedang \\
$0,70 \leq \mathrm{g} \leq 1,00$ & Tinggi \\
\hline
\end{tabular}

\section{Hasil dan Pembahasan}

Penelitian ini dilakukan di SMP Negeri 1 Bukit Kec. Bukit Kab. Bener Meriah tahun ajaran 2018/2019. Sampel yang diambil 24 siswa kelas di VIII ${ }^{1}$. Pada penelitian ini diajarkan dengan menggunakan Pendekatan Reciprocal Teaching yang bertujun untuk mengetahui kemmapuan berpikir kritis siswa pada saat pembelajaran dimulai. Data pada penelitian ini adalah data yang terkumpul dari hasil pretest dan posttest, posttest berupa tes kemampuan berpikir kritis matematis siswa yang dilaksanakan setelah pembelajaran selesai.

Adapun nilai pretest dan posttest adalah sebagai berikut:

Tabel 3. Nilai pretest dan posttest siswa

\begin{tabular}{lrr}
\hline & \multicolumn{2}{c}{ Nilai } \\
\cline { 2 - 3 } & Pretest & Postest \\
N (Sampel) & 24 & 24 \\
Rata - rata & 31.04 & 63.75 \\
Simpangan Baku (S) & 13.51 & 17.6 \\
NilaiTertinggi & 55 & 95 \\
NilaiTerendah & 0 & 20 \\
\hline
\end{tabular}

Setelah proses pembelajaran reciprocal teaching terjadi peningkatan kemampuan berpikir kritis matematika siswa. Nilai pretest dan postes yang diperoleh siswa akan diuji oleh uji gain ternormalisasi untuk mengetahui peningkatan kemampuan berpikir kritis matematis siswa, dan setiap siswa mengalami peningkatan yang berbeda-beda. Seperti terlihat pada table berikut ini:

Tabel 4. Nilai Gain dariSiswa

\begin{tabular}{rlrrrl}
\hline No & Nama & Skor Pretest & \multicolumn{2}{l}{ Nilai Postest } & \multicolumn{2}{l}{ Nilai Gain } & Kategori \\
\hline 1 & Res 001 & 0 & 36 & 0.6 & Sedang \\
2 & Res 002 & 11 & 34 & 0.469388 & Sedang \\
& & & & & \\
3 & Res 003 & 15 & 47 & 0.711111 & Tinggi \\
4 & Res 004 & 7 & 22 & 0.283019 & Rendah \\
5 & Res 005 & 18 & 56 & 0.904762 & Tinggi \\
6 & Res 006 & 12 & 37 & 0.520833 & Sedang \\
7 & Res 007 & 11 & 34 & 0.469388 & Sedang \\
8 & Res 008 & 6 & 19 & 0.240741 & Rendah \\
9 & Res 009 & 7 & 22 & 0.283019 & Rendah \\
10 & Res 010 & 6 & 19 & 0.240741 & Rendah \\
\hline
\end{tabular}


Jurnal As-Salam Vol. 3 No. 2 Mei - Agustus 2019: 29 - 37

Rosliana Harahap, Betri Yustianingrum, Ilhamdi

\begin{tabular}{rrrrrl}
\hline 11 & Res 011 & 12 & 37 & 0.520833 & Sedang \\
12 & Res 012 & 7 & 22 & 0.283019 & Rendah \\
13 & Res 013 & 6 & 19 & 0.240741 & Rendah \\
14 & Res 014 & 11 & 34 & 0.469388 & Sedang \\
15 & Res 015 & 18 & 56 & 0.904762 & Tinggi \\
16 & Res 016 & 7 & 22 & 0.283019 & Rendah \\
17 & Res 017 & 6 & 45 & 0.722222 & Tinggi \\
18 & Res 018 & 11 & 34 & 0.469388 & Sedang \\
19 & Res 019 & 11 & 34 & 0.469388 & Sedang \\
20 & Res 020 & 6 & 34 & 0.518519 & Sedang \\
21 & Res 021 & 12 & 37 & 0.520833 & Sedang \\
22 & Res 022 & 12 & 37 & 0.520833 & Sedang \\
23 & Res 023 & 13 & 41 & 0.595745 & Sedang \\
24 & Res 024 & 18 & 56 & 0.904762 & Sedang \\
Jumlah & 243 & 745 & 12.1 & & \\
& & & 4645 & & Sedang \\
Rata- & 10,12 & 31,04 & 0.506102 & & \\
rata & & & & & \\
\hline
\end{tabular}

Dari hasil pengamatan selama penelitian didapat bahwa dalam pengajaran terbalik (Reciprocal Teaching) terlihat bahwa siswa lebih bersemangat dalam proses pembelajaran. Hal ini disebabkan karena setiap anggota kelompok mendapat tugas secara bergantian untuk menjelaskan materi didepan kelas dan menjawab setiap pertanyaan dari teman-temannya, sehingga melatih siswa untuk berpikir lebih kritis, dan lebih menghargai masukan-masukan atau pendapat dari teman temannya dan dapat bertanggung jawab dalam menjalankan tugas yang diberikan oleh guru, sehingga siswa juga mendapatkan suasana belajar yang baru, menyenangkan, dan tidak membosankan. Hal ini sejalan Erni (2013 vol.2. No.1 hal.13) yang menyatakan Model Reciprocal Teaching adalah suatu model pembelajaran yang merupakan tempat strategi pemahaman mandiri, yaitu menyimpulkan bahan ajar, menyusun pertanyaan dan menyelesaikanya, mejelaskan kembali pengetahuan yang telah diperolehnya, kemudian memprediksi pertanyaan selanjutnya dari persoalan yang disodorkan kepada siswa.

Berpikir kritis matematis adalah kemampuan intelektual yang dimiliki seseorang untuk memahami permasalahan matematika. Mereka mampu menganalisis permasalahan tersebut, dan dapat memutuskan solusi yang sesuai dari permasalahan tersebut. Berpikir kritis matematis juga dapat didefinisikan sebagai kemampuan berpikir logis dan reflektif yang fokus pada cara mengambil keputusan yang dapat dipercaya. Oleh karena itu, seseorang yang memiliki kemampuan berpikir kritis matematis memiliki kemampuan intelektual dengan berpikir logis dan reflektif dalam memahami permasalahan matematika, menganalisis permasalahan, dan memutuskan solusi yang tepat (Rully \& Charitas, 2017).

Kemampuan berpikir kritis matematika menurut Ennis adalah berpikir reflektif yang berfokus pada pola pengambilan keputusan tentang apa yang harus diyakini dan dilakukan. Berdasarkan definisi tersebut indikator berpikir kritis dapat dibagi menjadi 5 kelompok, yaitu: (1) memberikan penjelasan sederhana (elementary clarification), (2) 
membangun keterampilan dasar (basic support), (3) membuat kesimpulan (inferring), (4) membuat penjelasan lebih lanjut (advanced clarification), (5) mengatur strategi dan teknik (strategies and tactics) (Ennis, 2011). Kelima indikator berpikir kritis siswa sejalan dengan model pembelajaran reciprocal teaching, sehingga melalui pembelajan ini terjadi peningkatan kemampuan berpikir kritis siswa. Adapun tujuan dari berpikir kritis matematis adalah untuk mencapai pemahaman yang mendalam. Pemahaman membuat siswa menngerti maksud dibalik ide yang mengarahkan hidup siawa setiap hari. Pemahaman mengungkapkan makna dibalik suatu kejadian siswa pada saat belajar matematika.

Dalam proses pembelajaran menggunakan pendekatan pengajaran terbalik (Reciprocal Teaching) pada materi relasi dan fungsi, pola pikir siswa dilatih untuk menganalisa, mengevaluasi dan mencipta permasalahan-permasalahan atau soal-soal yang ditawarkan baik dalam bentuk tugas kelompok maupun secara individu. Mamfaatnya adalah dapat meningkatkan antusias siswa dalam pembelajaran karena siswa dituntut untuk aktif berdiskusi dan menjelaskan hasil pertanyaan dengan baik sehingga penguasaan konsep suatu pokok bahasan matematika dapat dicapai. Adapun kelebihan tipe Pembelajaran Reciprocal Teaching adalah dapat meningkatkan kemampuan dan keinginan siswa untuk membaca, siswa yang memilki cita-cita jadi guru, akan termotivasi dengan tersendirinya, karena ia diberikan kesempatan untuk memerankanya jadi guru, dapat meningkatkan daya ingat siswa terhadap pengetahuan yang di perolehnya, karena ia menerpakan secara langsung melalui pemodelan yang diberikan kepadanya, membuat siswa aktif dalam mengikuti proses belajar mengajar, meminimalkan peranan guru dalam proses belajar menagajar.Melalui model reciprocal terdapat peningkatan kemampuan berpikir kritis matematis siswa sebesar 0,506 dalam kategori sedang.

Pendekatan reciprocal teaching memilki hubungan denagn komponen-komponen berpiki kritis seperti yang telah dikemukakan oleh Swar an Park dalam Anitah: "Untuk meningkatkan kemampuan berpikir kritis, siswa harus dapat membaca dengan kritis yang merupakan langkah awal dari strategi reciprocal teaching, kemudian berdasarkan indikato indikator kemampuan berpikir kritis siswa dapat menjawab pertanyaan yang membutuhkan penjelasan, selain itu siswa harus mampu membuat kesimpulan, dalam hal ini dapat membuat generalisasi, dalam berpikir kritis siswa juga harus dapat memprediksi pertanyaan-pertanyaan yang mungkin muncul" (Anitah dan Janet, 2009).

Cara siswa mempelajari empat kegiatan di atas adalah dengan mengambil giliran berperan sebagai guru selama kegiatan membaca didalam kegiatan kelompoknya masingmasing. Apabila salah satu temanya bertindak/berperan sebagi guru atau pemberi materi. Reciprocal Teaching (pengajaran terbalik) adalah prosedur pengajaran yang digunakan Brown dan Palincsar untuk mengembangkan kemampuan kognitif. "Selain pemantauan kognitif, ada dua kegiatan kognitif lainnya yang amat penting dalam kaitan dengan keterampilan kognitif sehari-hari, yaitu pengambilan keputusan dan berpikir kreatif'.Sehingga dapat dijadikan sebagai salah satu alternatif metode pembelajaran yang cukup dianggap menarik, dan diharapkan dapat mendorong dan meningkatkan siswa untuk berpikir kreatif dalam pembelajaran matematika.

Berdasarkan interpretasi diatas peneliti dapat menyampaikan bahwa pendekatan pengajaran terbalik (Reciprocal Teaching) yang digunakan dalam penelitian di SMP Negeri 1 Bukit memberikan dampak positif yaitu siswa terlihat lebih bersemangat dan dilatih untuk berpikir lebih kritis dalam belajar matematika sehingga dapat dijadikan sebagai salah satu alternatif untuk meningkatkan mutu pembelajaran yang mungkin dapat dilaksanakan di kelas. 


\section{Kesimpulan dan Saran}

1. Kesimpulan

Berdasarkan analisis data di atas, dapat disimpulkan bahwa:

a. Terdapat peningkatan kemampuan berpikir kritis matematis siswa melalui metode reciprocal teaching dalam kategori rendah sebanyak 7 orang, kategori sedang 13 orang, kategori tinggi sebanyak 4 orang. Rata-rata peningkatan kemampuan berpikir kritis matematika siswadalam kategori sedang yaitu sebesar 0.506 .

b. Metode reciprocal teaching dapat meningkatkan minat belajar matematika siswa.

c. Metode reciprocal teaching membuat siswa lebih aktif dalam proses pembelajaran di kelas.

2. Saran

a. Guru

Kepada guru khususnya guru mata pelajaran matematika kiranya berkenan mencoba menggunakan model pembelajaran reciprocal teaching ini agar dapat meningkatkan kemampuan berpikir kritis matematis supaya siswa tertarik dan termotivasi dalam belajar, hendaknya guru selalu melibatkan siswa secara aktif dan membuat suasana yang menyenangkan dalam peroses belajar mengajar sehingga siswa tidak beranggapan bahwa matematika pelajaran yang sulit dan memiliki pengaruh positif dalam rangka meningkatkan kemampuan berpikir kritis siswa terhadap matematika.

b. Siswa

Supaya siswa lebih meningkatkan kembali keaktifan dalam proses belajar mengajar, karena setiap metode maupun model pembelajaran yang diajarkan oleh guru tidak akan mendapatkan hasil maksimal apabila siswa tidak berperan aktif dalam proses belajar mengajar. Dengan demikian siswa dituntut untuk lebih aktif, sehingga apapun yang disampaikan guru siswa mampu menerima materi pelajaran dengan baik dan mendapatkan hasil belajar yang maksimal.

\section{Daftar Pustaka}

Arikanto, Suharsimi. 2012. Dasar-dasar Evaluasi Pendidikan. Jakarta: Bumi Aksara.

Awaliah , Reski \& Ridwan Idris. "Pengaruh Penggunaan Model Reciprocal Teaching Terhadap Hasil Belajar Matematika Siswa Kelas VIII MTsN Balang-Balang Kecamatan Bontomarannu Kabupaten Gowa". Jurnal Matematika dan Pembelajaran. Volume 3 Nomor 1Juni 2015.

Ennis, R.H.2011. The Natureof thinking: An Outline of Critical Thinking Despositionand Abilities. USA: University of Illinois.

Meltzer, David, E. 2002. The Relationship betweenMathematics Preparation and Conceptual Learning Gain in Physics: A Possible Hidden Variable in Diagnostic Pretest Scores. Teaching and Teacher Education, 8 (3), 275-286.

Rully, Oktavia Filda Yanti \& Charitas Indra Prahmana, “ Model Problem Based Learning Guide Inqury dan Kemampuan Berpikir Kritis Matematis". Journal Review Pembelajaran Matematika (JRPM). Vol 2.2 Tahun 2017.

Sugiono.2015.Metode Penelitian Pendidikan, (Bandung: Alfabeta, 2015), hal .110-111

Sri Anitah dan Janet Manoy.2009. Strategi Pembelajaran Matematika. Jakarta: Kencana Prenada Media Group. hal.24.

Sundayana, Rostiana.2014. Statistika Penelitian Pendidikan. Bandung : Alfabeta.

Zainal Arifin. 2016. Penelitian Pendidikam. Bandung: Remaja Rosdakarya, hal. 226. 